ТЕОРЕТИКО-ПОНЯТІЙНІ АСПЕКТИ ІНКЛЮЗИВНОЇ ОСВІТИ В СУЧАСНИХ ПЕДАГОГІЧНИХ ДОСЛІДЖЕННЯХ

\title{
THEORETICAL AND CONCEPTUAL ASPECTS OF INCLUSIVE EDUCATION IN MODERN PEDAGOGICAL RESEARCHES
}

\author{
Стаття присвячена аналізу поняттєвого \\ апарату інклюзивної освіти, виявленню осо- \\ бливостей інтерпретацій понять «інклю- \\ зія», «інтеграція», «інклюзивна освіта». \\ Дослідження проведено на основі діахронно- \\ синхронного підходу, що дозволяє не тільки \\ виявити особливості термінологічної інтер- \\ претації основних понять, які входять до \\ категорії «інклюзія», але й дає змогу просте- \\ жити специфріку орормування поняттєвого \\ апарату відповідно до загальних тенденцій \\ розвитку педагогічної, суспільно-фрілософр- \\ ської, соціально-медичної думки. \\ Установлено, що між інтеграційною та \\ інклюзивною педагогікою прослідковуються \\ різні концепції, стадії розвитку, підходи до \\ розуміння засадничих принципів тракту- \\ вання поняття «діти з особливими освіт- \\ німи потребами». З'ясовано, що поняття \\ «інтеграція» асоціюється здебільшого \\ 3 терміном «толерантність», а «інклю- \\ зія»- 3 таким поняттям, як «сприйняття». \\ Отже, діти з особливими освітніми потре- \\ бами сприймаються в контексті інклюзив- \\ ної педагогіки як рівноправні, тобто без \\ будь-яких застережень такими, якими вони \\ $\epsilon$, які можуть розраховувати на підтримку \\ ближніх. \\ Підкреслено, що інклюзивна фоорма навчання \\ $\epsilon$ пріоритетним механізмом включення \\ дітей 3 особливими потребами до освіт- \\ нього середовища, в якому забезпечення \\ основного права будь-якої дитини на освіту \\ за місцем проживання реалізується через \\ систему освітніх послуг, закріплених на \\ законодавчому рівні. З'ясовано, що інклюзія \\ в освіті базується на різнорідності дітей не \\ тільки з огляду на певні психофізичні відмін- \\ ності, але й на стать, національність, расу, \\ мову, соціальний статус. \\ Встановлено, що завдання інклюзії - це \\ надання різноманітних освітніх можливос- \\ тей усім дітям незалежно від їхньої соці- \\ ально-культурної, етнічної, лінгвістичної \\ приналежності.
}

Ключові слова: інклюзія, інтеграція, інклюзивна педагогіка, неповносправність, різнорідність, діти з особливими потребами.

The article focuses on the analysis of an inclusive education conceptual apparatus; revealing the interpretation peculiarities of the concepts "inclusion", "integration", "inclusive education". The research has been conducted on the basis of a diachronous synchronous approach, which not only reveals the features of a terminological interpretation of the basic concepts that are included in the category "inclusion", but also allows to trace the specifics of the conceptual apparatus according to the general tendencies development of the pedagogical, social and philosophical, social and medical thought formation.

It has been determined that different concepts, the stages of development, the approaches to understanding the basic principles of interpretation of the phrase - "children with special educational needs" are traced between the integration and inclusive pedagogy. It has been found out that the term "integration" is mostly associated with the term "tolerance" and "inclusion" with such a term as "perception". Accordingly, in the context of inclusive pedagogy the children with the special educational needs are perceived as equal, without any admonition, as they are, they can account on the support of their surrounding. It has been emphasized that an inclusive form of education is a priority mechanism for inclusion of children with special needs in the educational environment, in which ensuring the basic right of any child to education at the place of residence is realized through the system of educational services, fixed at the legislative level. It has been found out that inclusion in education is based on the diversity of children not only in view of certain psychophysical differences, but also on gender, nationality, race, language, social status.

Key words: inclusion, integration, inclusive pedagogy, the disabled, diversity, children with special needs.
Постановка проблеми у загальному вигляді. Впровадження інклюзивної освіти в Україні демонструє нагальну потребу суспільства у підтримці та зміні ставлення до осіб з особливими потребами. Розбудова українського суспільства детермінує необхідність включення осіб 3 особливими потребами до його соціального простору, гарантуючи при цьому захист їхніх прав та усебічну підтримку. Пріоритетними напрямами у цьому процесі постають надання якісної освіти та підготовка до життя у сучасному суспільстві дітей з особливими потребами.

Важливим етапом у поступі інклюзивної освіти у світі було прийняття Саламанської декларації (1994р.), в якій були визначені такі її концептуальні засади: гуманне ставлення до дітей з особливими потребами; упровадження шкіл 3 інклюзивною орієнтацією; створення відповідного освітнього середовища; врахування інтересів, здібностей та навчальних потреб усіх дітей тощо [9]. Слід також наголосити, що Україна, ратифрікувавши у 2010 році Міжнародну Конвенцію про права інвалідів [6], в якій цілий розділ був присвячений інклюзивній освіті, взяла на себе зобов'язання виконувати усі перелічені в ній пункти. Це сприяло широкому розповсюдженню засадничих ідей, положень, принципів інклюзивної освіти в Україні, зокрема й в педагогічній теорії і практиці.

Аналіз останніх досліджень і публікацій. Сучасні дослідження в галузі спеціальної педагогіки підтверджують актуальність окресленої проблеми. Так, у працях Н. Денисенко, І. Дичківської, Т. Ілляшенко, А. Колупаєвої [4], О. Кучерявого, Н. Ліфінцевої, П. Таланчука та ін. особлива увага 
була приділена проблемам навчання й виховання дітей 3 особливими потребами у різних типах загальноосвітніх закладів на сучасному етапі. Підготовці педагогічних кадрів до роботи 3 дітьми 3 особливими потребами присвячені дослідження Л. Артюшкіної, Ю. Бекетової, О. Бородіної [1], М. Васильєвої, І. Доброскок [2], І. Рассказової, Л. Штефран та ін. Окремі психолого-педагогічні основи організації освітнього середовища та професійного супроводу дітей з особливими потребами в умовах освітнього середовища висвітлені у працях Г. Гавриленко, Л. Гречко, В. Засенко, І. Омельченко, Т. Сак [8], Т. Скрипник.

Реалізація суспільством системи опіки над дітьми з особливими освітніми потребами передбачає глибокий аналіз різних підходів щодо визначення її ефективності. Свідченням цього $€$ велика кількість праць, що присвячені різним теоретикометодичним аспектам інклюзії в Україні та за кордоном, порівняльному аналізу правових та організаційних засад інклюзивного й інтегративного навчання, проблемам підготовки фрахівців у цій галузі. Водночас слід зазначити, що дослідження термінологічного апарату з обраної теми не $є$ широко представленим. Зокрема, йдеться про розмежування термінів «інтеграція» та «інклюзія», які доволі часто ототожнюються сучасними науковцями. Зазначимо, що побіжно цієї проблеми торкалися І. Гладченко, Н. Заєркова [3], А. Колупаєва [5], Л. Перхун, Т. Ткаченко [10], А. Трейтяк. Проте недостатня увага науковців до аналізу поняттєвих аспектів інклюзії увиразнює актуальність цього дослідження.

Мета статті - здійснити категорійно-понятійний аналіз інклюзивної освіти в Україні на сучасному етапі крізь призму діахронно-синхронного підходу.

Виклад основного матеріалу Застосування діахронно-синхронного підходу дозволяє не тільки виявити особливості термінологічної інтерпретації основних понять, що входять до категоріального поля «інклюзія», але й дає змогу простежити специфіку формування поняттєвого апарату відповідно до загальних тенденцій розвитку педагогічної, суспільної, соціально-медичної, фрілософської думки у різні часові проміжки.

У розвитку інклюзивної освіти ключову роль відіграли ідеї про навчання й виховання неповносправних дітей, їхню соціалізацію. Зокрема, йдеться про дослідження особливостей їхнього психофізичного розвитку та їх здатності навчатися (медичний складник), їх здатність сприймати освітню програму, здатність до вироблення соціально-поведінкових навичок (психолого-педагогічний складник), фрункціонування призначених для них середовищ (медико-педагогічний складник).

Тому надзвичайно важливим є завдання якомога більшого ранжування неповносправності. Серед видів неповносправності виділяють такі: а) аборт - різні способи позбавлення життя неповносправних дітей (відбувається до народження дитини, коли з'ясовується, що плід недорозвинутий); б) відмова рідних батьків від дитини (дитину можуть забрати прийомні батьки або вона опиниться у спеціальних закладах); в) виключення (всі недорозвинуті діти, які не відповідають освітнім нормам, виключаються 3 навчально-виховного процесу); г) селекція (сегрегація) передбачає, що неповносправні діти, які досягають шкільного віку, поділяються на відповідні підгрупи.

ще на початку XXI століття вважалося, що найкращі умови для навчання неповносправних дітей мають гомогенні групи [12]. Відповідно до такого поділу система навчання дітей реалізувалася як у загальноосвітніх школах, так і в спеціальних. Спеціальні школи ділили своїх учнів відповідно до окремих типів неповносправності.

Необхідно зауважити, що селекційне (сегрегаційне) навчання передбачає також інтеграцію осіб з особливими освітніми потребами у нормальне суспільство, але проєкти такої інтеграції $€$ досить довготривалими і можуть реалізовуватись на основі сегрегаційного навчання.

Інтеграція поєднує рівномірне фрункціонування двох субсистем - сегрегаційної (селекційної) та інтеграційної. Діти з особливими освітніми потребами можуть за певної підтримки відвідувати загальноосвітні школи. Якщо інтеграція не дає есрективного результату, то дитина може повернутися до спеціалізованої школи.

Інклюзія як засаднича ідея успішної інтеграції переходить у нову і цілком відмінну за якістю фрорму. У цій системі освіти роль гомогенності вже не $€$ домінантною. Навпаки, тут на перше місце виступає гетерогенність.

Акцептація гетерогенності в інклюзивній освіті включає у себе, крім гуманітарного аспекту, також і методологічний аспект, який полегшує працю вчителя загальноосвітньої школи, адже зникає необхідність засвоєння усіма учнями одного стандарту навчання, що значно ускладнювало роботу вчителя. Різнорідність стає нормою, а інклюзія - цілком звичайним явищем у педагогічній практиці [13].

Важливо зауважити, що проблемою інтегративного навчання займалася спеціальна педагогіка. Однією із засад процесу ії інституціоналізації була фрагментація. Зокрема, ідеться про заснування перших спеціальних закладів для неповносправних дітей. Перші успішні заклади для дітей з особливими освітніми потребами (неповносправними) почали з'являтися у Європі у XVIII ст. У цей час також відбувалася й організація спеціальних установ (медичних, освітніх, суспільних), які опікувалися дітьми з особливими освітніми потребами. Перші такі інституції досить часто розміщували у себе дітей з різними вадами. 3 часом тут почали 
концентруватися на специорічних дисорункціях (елементах найтиповіших неповносправностей).

Досить високу есрективність роботи показали школи, які спеціалізувалися на різних видах неповносправності, особливо розумової відсталості. У деяких країнах Європи заклади для дітей з порушеннями слуху і надалі звужували свою спеціалізацію. Це привело до того, що були створені відділи для глухих дітей, для дітей зі слабким слухом та дітей з надмірною вразливістю слуху.

На кінець XIX - початок XX ст. утверджується думка науковців, яка закріплюється на законодавчому рівні у багатьох європейських країнах, про необхідність навчання неповносправних дітей трьохтакихкатегорій:глухих, сліпихтарозумововідсталих [7]. Упродовж XX століття фрормуються ідеї інтегративного навчання, що проявилися у закріпленні законодавчої бази спеціальної педагогіки, виробленні моделей інтеграції дітей з особливими потребами у звичайне навчальне середовище.

Саме через ознаки інтеграції дитини 3 особливими потребами до освітнього середовища досить часто виникає нерозуміння відмінностей між інклюзивною педагогікою та інтеграційною педагогікою. Інколи інклюзивна педагогіка ототожнюється $з$ інтеграційною, а інколи трактується як покращений варіант інтеграційної.

Зауважимо, що у разі інклюзивної педагогіки йдеться про зовсім іншу якість, ніж інтеграція, a саме про забезпечення спеціальних освітніх потреб для всіх дітей.

Організація Об'єднаних Націй у своїй Конвенції щодо прав неповносправних осіб у пункті, що стосується навчання, користується таким терміном, як «система інклюзивної освіти» (inclusive education system). У цій системі різнорідність $€$ нормою. Якщо інтегративна система освіти передбачає пристосування дитини до освітнього середовища, то інклюзивна система намагається пристосувати освітнє середовище до дитини.

Між інтеграційною та інклюзивною педагогікою прослідковуються різні концепції, стадії розвитку дітей з особливими освітніми потребами. Оскільки інтегративна концепція була предметом дебатів у різних країнах світу у кінці XX ст., то на початку XXI ст. чітко увиразнюється тенденція домінування інклюзивної педагогіки.

Якщо поняття «інтеграція» асоціюється здебільшого $з$ терміном «толерантність», то інклюзія вже пов'язується 3 таким поняттям, як «сприйняття». Відносно дітей 3 особливими освітніми потребами з огляду на їх інклюзивність мова йде про речі більш засадничі, тобто про сприйняття апріорі свого ближнього, а не тільки толерування неповносправної людини, якій створили умови для існування серед інших. Учень 3 особливими освітніми потребами повинен сприйматися без будь-яких застережень, тобто таким, яким він є.
Нашим сприйняттям ми не тільки декларуємо, але й трактуємо особу з особливими освітніми потребами як рівну нам. Така особа може розраховувати на нашу підтримку. Допомагаючи їй, ми тим самим збагачуємо себе. Поступова соціалізація особистості приводить до якісного зростання етичної свідомості суспільства, а також кожного індивідуума, який бере участь у цьому процесі.

Між інтеграційною педагогікою та інклюзією існує суттєва різниця і щодо їхніх класиорікацій. При реалізації інтеграційного навчання використовується така триступенева класифікація: локальна інтеграція, суспільна інтеграція, а також фрункціональна інтеграція.

Локальна інтеграція передбачає спеціальні класи для дітей з особливими освітніми потребами, які відносяться до середовища загальноосвітньої школи, при цьому неповносправні учні не контактують між собою та здоровими колегами. що стосується суспільної інтеграції, то між обома групами діти здійснюють інтеракції через різні фрорми суспільної активності, але більша частина проведеного спільно часу припадає на сегрегацію (поділ за формами неповноправності). Функціональна інтеграція передбачає навчання дітей 3 особливими освітніми потребами у звичайних класах.

Застосовуючи інклюзивну педагогіку у шкільній практиці, не слід забувати про конкретну мету, яку вона ставить перед собою. Цією метою є перехід від моделі інтеграції осіб з особливими освітніми потребами до інклюзивної моделі з гаслом «Школа для всіх дітей» [11].

У полі зору інклюзивної педагогіки перебувають також проблеми від класичних відхилень у розвитку дітей та молоді, які відомі у суспільстві (сліпі, глухі, фрізично та розумово неповносправні тощо), аж до загроз оптимальному розвитку дитини, що можуть бути викликані побічними явищами, які дитина пережила в реальному житті. Це можуть бути хронічні хвороби або несприятливе суспільне середовище (зокрема, діти-шульги, яких змушують писати правою рукою, важковиховувані діти і діти з особливими здібностями, яким приділяють недостатньо уваги у класі).

Переорієнтація інтеграційного підходу на інклюзивний у системі навчання й виховання дітей та молоді $з$ особливими освітніми потребами стала не просто зміною напряму розвитку. Під час інтеграції учень повинен пристосовуватися до школи. Це не означає, що школа повинна змінитися, щоб підкреслити гетерогенність учнів.

На противагу інтеграції інклюзія імплікує радикальну реформу освіти у сорері оновлення шкільних програм, оцінювання і створення учнівських груп, суспільних середовищ. Такий підхід базується на сприйнятті різнорідності 3 огляду на стать, національність, расу, мову, соціальний статус, неповносправність тощо. 
Водночас зазначимо, що у контексті інклюзивної педагогіки термін «особливі освітні потреби» тлумачиться крізь призму соціальної моделі, в якій вони сприймаються як своєрідні труднощі, з якими стикаються учні. Медична модель, що більш характерна для інтеграційного підходу, базується на сприйнятті особливих освітніх потреб як обмежень самої дитини в процесі навчання. Отже, соціальна модель передбачає подолання труднощів, які виникають у результаті взаємодії учнів з освітнім середовищем, різними культурами, адміністрацією, навіть навчальним матеріалом, а медична модель акцентує увагу на вадах дітей, що заважають сприймати навчальний матеріал, виділяють їх 3-поміж інших учнів.

Інклюзивна освіта починається 3 визнання відмінностей, які існують між учнями. Тобто визнання, що кожна дитина особлива, має свої фрізичні й психологічні особливості і потребує поваги й розуміння з боку усіх учасників навчально-виховного процесу, стає основоположним у сучасній освітній парадигмі. Розвиток такого підходу передбачає комплексну орієнтацію на зосередження уваги на особистості в цілому, а не на окремих її аспектах. Наголосимо, що інклюзія передбачає зменшення усіх перешкод у навчанні для всіх учнів без винятків. Інклюзивна освіта має на меті створення сприятливого та стимулюючого середовища і для учнів, і для персоналу, в якому підтримка, допомога і взаємодопомога визначаються як такі види діяльності, що сприяють підвищенню здатності школи своєчасно реагувати на різноманітність своїх учнів.

Висновки. Як було з'ясовано, типовим фрокусом багатьох дослідників інклюзії в освіті $€$ орієнтація на осіб з інвалідністю. Однак, досліджуючи поняттєвий апарат проблеми, завдання інклюзії слід розуміти більш широко, тобто як надання різноманітних освітніх можливостей усім дітям незалежно від їхньої соціально-культурної, етнічної, лінгвістичної приналежності.

Можемо констатувати, що інклюзивна освіта спрямована на залучення дітей 3 особливими потребами до різноманітнішого матеріалу, ширшого соціального кола, що покращує їхні соціальні навички та вміння вирішувати конкретні проблеми. Інклюзія в школі також покращує відносини між усіма учнями, здійснює позитивний вплив на однолітків, сприяючи фрормуванню нових цінностей, дружніх відносин, самостійності усіх учнів.

Інклюзивна освіта базується на трьох основних засадах: 1) доступності (забезпеченні широкого спектру діяльності та освітнього середовища для кожної дитини з урахуванням її особливостей); 2) участі (використанні низки інструктивних та інтервенційних підходів, що сприяють активному залученню до ігрової й навчальної діяльності всіх учнів. Реалізація таких підходів сприяє соціально-емоційному й поведінковому розвиткові кожної окремої дитини); 3) підтримці (розробці інфраструктури та політики навчального закладу, що базується на наданні спеціалізованих послуг та терапії дітям з особливими потребами, можливості співпраці з родиною та іншими профресіоналами для підтримки високої якості включення дітей в освітнє середовище).

\section{БІБЛІОГРАФІЧНИЙ СПИСОК:}

1. Бородіна О.С. Підготовка майбутнього вчителя основ здоров'я до професійної діяльності в умовах інклюзивного навчання : дис. ... канд. пед. наук : 13.00.04 ; ХНПУ ім. Г.С. Сковороди. Харків, 2014. 254 c.

2. Доброскок І. До проблеми підготовки магістрів соціальної педагогіки. Рідна школа. 2010. № 3. C. 10-13.

3. Інклюзивна освіта від А до Я: порадник для педагогів і батьків / укладачі Н.В. Заєркова, А.О. Трейтяк. Київ, 2016. 68 с.

4. Колупаєва А.А. Інклюзивна освіта: реалії та перспективи : монограсрія. Київ : САММІТ-книга, 2008. 272 c.

5. Колупаєва А. Інклюзивна освіта як модель соціального устрою. Особлива дитина: навчання і виховання. 2014. № 2. C. 7-18. URL: http://nbuv.gov.ua/ UJRN/DLog_2014_2_3 (дата звернення: 02.11.2019).

6. Конвенція про права інвалідів ООН Міжнародний документ від 13.12.2000 p. URL: http://zakon4.rada.gov.ua/laws/show/995_g71 (дата звернення: 01.11.2019).

7. Малофреев Н.Н. Западная Европа: эволюция отношения общества и государства к лицам с отклонениями в развитии. Москва: Экзамен, 2003. 256 с.

8. Сак Т. Організація навчального процесу в інклюзивному класі. Дефректологія. 2011. № 2. С. 8-11.

9. Саламанська декларація про принципи, політику та практичну діяльність у галузі освіти осіб 3 особливими освітніми потребами URL: https://zakon.rada.gov.ua/laws/show/995_001-94 (дата звернення: 01.11.2019).

10. Ткаченко Т. Від інтеграції до інклюзії. Директор школи. Шкільний світ. 2016. № 9-10. С. 79-91.

11. Biewer G. Grundlagen der Heilpädagogik und inklusiven Pädagogik. Klinkhardt : Bad Heilbrunn, 2009. $270 \mathrm{~s}$

12. Ravaud F.-F.Stiker. Inklusion and exclusion. Encyklopedia of disability. Sage : Thousand Oaks, 2006. P. 923-927.

13. Scholz M. Der Weg von Integration zur Inklusion. Sonderpädagogik. Bayern, 2007. T. 50. № 1. S. 2-9. 